\title{
Multicultural Value Reinforcement through Scouting Activities
}

\author{
Suyahman \\ Elementary School Teacher Education Department \\ Faculty of Teacher Training and Education \\ Universitas Bantara Sukoharjo \\ Sukoharjo, Indonesia \\ sym_62@yahoo.com
}

\begin{abstract}
This study aims to describe the multicultural value reinforcement through scouting activities. It is a qualitative research using a descriptive approach. Data analysis technique employed was the interactive analysis technique consisting of 3 stages namely data reduction, data display, and data verification. The results showed that multicultural values of mutual respect and attitudes of concern to friends in school were less optimal. It can be seen from the students' attitude and behavior in choosing friends, group discussions, visiting friends/ parents. If this condition is left, it can damage the unity and unity of students at school and in general. Scouting program as one of the government policies is an extra-curricular activity mandatory at schools. It can be a means of strengthening multicultural values as a solution to this current problem. The results of the observation conducted from July to August 2017 on the attitudes, behaviors and deeds of students showed a very significant change. Students were no longer considered the differences in religion, ethnic, customs, culture and language in forming a discussion group, visiting their sick friends, and helping others. The multicultural values adopted in scouting activities through Dasa Dharma scout of faith to God Almighty, love nature and compassion of humanity, obedient and receptive to deliberation, helpful and steadfast, responsible, trustworthy and saints in mind, word and deed becomes the basis for reinforcing of multicultural values for the seventh grade students of SMP Negeri 1 Kartasura. In conclusion, the scouting activities based on Dasa Dharma reinforce the students' multicultural value.
\end{abstract}

Keywords-multicultural values, reinforcement, scouting activities

\section{INTRODUCTION}

The people of Indonesia, as one of the cultural groups that grow in the nature of Indonesia have a unique and diverse culture. One of the uniqueness of Indonesian culture is multiculturalism. In essence, multiculturalism is a worldview that can then be translated into cultural policies that emphasize acceptance of the religious, plurality, and multicultural realities that exist in the life of society. Multiculturalism can also be understood as a worldview which is then manifested in political consciousness [1].

According to [2], Indonesia is a plural country which has a potential to disasters as it consists of huge number of people. This is certainly inversely related to the notion of multiculturalism that supports the cultural policy to equalize all forms of differences. Often, multiculturalism faces obstacles to modernization as one of the challenges of global society continues to erode a national culture that seems to have no directional view of life. In fact, culture includes all the dynamics and realization to perfection or maturity. Meanwhile, the people of Indonesia themselves are difficult to crawl towards their maturity.

The society tends to be spoiled, accepting all the circumstances, and enjoying all that is given without any criticism of an action as well as the popular 'father-happy' principle in the Soeharto regime. This is then the mindset of the Indonesian nation. Most of them assume that as long as their position does not change and oppose by other people, they are safe.

Then, where are the youths where they are in charge of continuing to preserve multiculturalism. They seem to have been busy and sucked by the flow of globalization and westernization that continue to enter our country without any filter that can hold or filter it. What should we do next? Shut up and wait for the national culture to be replaced by other cultures so that our nation does not have a clear identity related to national identity? In fact, it is clear that the national culture that has developed and that has been manifest in all forms of life of the nation will affect the power of thought and creativity of the citizens of the nation itself.

The facts show the occurrence of the change of mindset, the pattern of action among students of the primary to secondary education in choosing a playmate, forming a discussion group, helping others, visiting friends who are sick, even helping the disaster of national and local disasters tend to distinguish people by tribe, religion, culture, customs, and language. Such conditions become a weakness and hinder the existence of multicultural in Indonesia. If this is allowed, it can be a threat to the BKRI. That is why the solution must be sought.

In addressing this issue, this study focused on reinforcing the multicultural value through scouting activities. It was conducted at SMP Negeri 1 kartasura academic year 20172018. The main reason for choosing this topic is based on the number of cases among junior high school students related to 
the trigger of the multicultural value weakness that can disrupt the integrity of the nation. On the other hand, the effort to preserve, maintain, and civilize the value of multicultural becomes the responsibility of all citizens of Indonesia. Therefore, junior high school students as the citizens are also responsible for preserving, maintaining, and civilizing the value of multicultural. In fact, it is necessary to reinforce the multicultural value for junior high school students through habits built in families, schools, and communities

Departing from the preliminary description above, the subject matter in this study can be formulated as follows: How do we reinforce the multicultural value of SMP Negeri 1 Kartasura students in the academic year 2017-2018?

The objective of this study is to describe the ways of reinforcing the multicultural value of SMP Negeri 1 Kartasura students in the academic year 2017-2018.

\section{LITERATURE REVIEW}

Ref [3] provides the definition of reinforcement as follows: "Reinforcement is any form of response that is part of a teacher's behavioral modification of student behavior which aims to provide information or feedback to the students for the actions of their response given as a encouragement or correction. Through the reinforcement skills provided by the teacher, the students will feel compelled forever to respond whenever stimuli arise from the teacher; or students will try to avoid responses that are considered not useful. Ref [4] gives the definition of reinforcement as a response given to students against the behavior or deeds that are considered good. The other definition given by [5] that reinforcement is a positive response to the behavior of students who are teachers so that students are actively engaged in learning.

Thus, the function of the reinforcement skills is to reward the students so that the students will be encouraged and increase their participation in every learning process. Ref [4] gives a similar definition as has been given by [6] who said the reinforcing is a response to positive behavior which may increase the likelihood of recurrence of such behavior. Reinforcement can be interpreted as a form of appreciation. This award does not have to be always tangible. It can also be in the form of words, smiles, nods, and touch. Ref [7] defines reinforcement as a teacher's behavior in responding positively to a student's particular behavior that enables the behavior to recur. Reinforcing itself aims to: (1) increase students' attention and activity, (2) facilitate the learning process, (3) generating and maintaining motivation, (4) controlling or changing disruptive attitudes towards productive learning behavior.

From several definitions of reinforcement, it can be concluded that reinforcement is any form of teacher's positive response to students' behavior. It is part of the teacher's behavioral modification of students' behavior that may increase the likelihood of recurrence of the behavior. Through the provision of reinforcement, students will be encouraged to respond whenever stimulus appears from the teacher, or students will try to avoid responses that are considered useless. Through reinforcing, students will feel to be encouraged and later increase their participation in every learning process.

Reinforcement principles have to be more meaningful. They should be given with regard to the following principles: devotional, warmth, and enthusiasm, clarity of target, speed and accuracy, and diversity. All of these principles must be done so that students avoid the saturation in following the learning.

The ultimate goal of reinforcement for good, positive attitudes, behaviors, and actions can be repeated so that it becomes a habit of daily living. Reinforcing in the context of attitude needs to be understood as an attempt to give positive response with the given reward against good and positive students' attitudes while following the scouting activities. Attitude is basically a positive or negative reaction to a particular person, object, or view [8]. Attitude can also be interpreted as a mental predisposition to perform an action. Attitudes are built from several components that are complex. Components of attitudes include: (1) cognitive components: based on the knowledge or information the individual has about the object of his attitude, (2) affective components: pleasure or displeasure, associated with values, (3) conative component: a person's readiness to behave in accordance with the object of his attitude.

Characteristics of attitudes include the attitudes inferred from the individuals' behavior, attitudes aimed at the psychological object, attitudes learned, and attitudes that influence behavior [9]. Meanwhile, according to [10], attitudes have the following characteristics: (1) value expressive function: attitude which communicates the value or identity that someone has against others and (2) ego defensive function: attitude to protect oneself, cover errors, and aggression in order to defend oneself.

Reinforcing attitudes can be maximized by providing reinforcement the theories of formation and understanding the attitude change. There are several theories of formation and attitude change. First, the Learning and Reinforcement Theory, based on this theory, attitudes are responses learned against specific stimuli. There is the procedure classical conditioning in this theory which is associated with a pleasant experience or vice versa. Individuals have a strong attitude towards a particular object through classical conditioning, for example, a child does not like certain races because his parents do not like either. Then, there are the reward and punishment processes. These are verbal and non-verbal attitudes reinforced by others. Then, the vicarious learning takes place through observation. Second, it is the Theory of Cognitive Consistency Balance. This theory shows how our attitude relates to others or a consistent object. This theory model involves a Perceiver $(\mathrm{P})$, another Person $(\mathrm{O})$, and another Object or a Person (X). All the three elements form a unity which can produce balance or imbalance. Imbalance will rise tension and pressure which encourage cognitive change to achieve balance. The third is the Cognitive Dissonance Theory [11]. Someone will experience the cognitive dissonance if he/she has ideas and thoughts simultaneously and contradictory. For example, a smoker who experiences dissonance generates tension that drives the dissonance down. 
In the context of strengthening the multicultural value, a coach scouting training should be always instill mutual respect, care, help, cooperation, and love by not discriminating religion, tribe, race, culture, and language.

The Scout Movement is an organization that organizes scouting education in Indonesia. As an organization, the Scout Movement certainly has its main tasks, goals, and functions. The objectives and functions of the Scout Movement are clearly described both in Law Number 12 Year 2010 on Scout Movement and in the Articles of Association and Bylaws of the Scout Movement. The main task of Scout Movement is to carry out education for young people out-of-class schedule. This education aims to complement education in the family and school environment. It is intended to achieve the objectives of the Scout Movement.

The purpose of the Scout Movement is to form every scout member to be a person who has a faith, cautious, noble character, patriotic soul, obey the law, and discipline. In addition, he/she upholds the value of nobility of the Indonesian nation, as well as possessing and mastering life skills. Finally, they are expected to become cadres of the nation that are able to maintain and build the Unitary State of the Republic of Indonesia, as well as practicing Pancasila and preserve the environment.

The achievement of these goals is expected to succeed in forming cadres of the nation as well as development cadres in Indonesia. Such personality is amongst the believer and insightful of science and technology. In addition, it is expected to form positive attitudes and behaviors, characterized by mastering skills and having mental, moral, spiritual, emotional, social, intellectual, and physical resilience. These attitudes will make people of Indonesia believe in their own ability, capable and able to build themselves and responsible for the development of society, nation, and state.

In addition to the main task and objectives above, the organization of the Scout Movement has a function. The function of the Scout Movement is in harmony with the main task of the Scout Movement. The function of Scout Movement is as an organizer of non-formal education outside school and family. The education becomes a forum for the development of young people with special characteristics. The special characteristic is the application of scouting principles, scouting methods, and among system in education conducted by Scout Movement. Apart from being a non-formal educational provider, the Scout Movement also serves as a forum for achieving the Scout Movement goals. To achieve these objectives, various efforts are made including scout education and training, scout development, community service and parents, and educational-oriented games.

\section{METHOD}

This research employs qualitative research. Ref [12] explains that qualitative research is one of the research procedures that produce descriptive data in the form of speech or writing and the behavior of people who observed. Qualitative approach is expected to produce a description depth in speech, writing, and/or behavior that can be observed from a specific individual, group, society, and/or organization within a certain context settings studied from the point of view intact, comprehensive, and holistic. Others argue that qualitative research is a study that intends to understand the phenomenon of what the subject of the research experiencing holistically is, and by way of description in the form of words and language, in a special context that is natural and by utilizing various scientific methods [13].

The study employed descriptive qualitative research. It attempts to tell the existing problem solving based on the data and intends to obtain information on reinforcing the multicultural values through scouting activities. The subjects of the research were the seventh grade of SMP Negeri 1 Kartasura students academic year 2017-2018. The objects of research were the multicultural value and scouting activities. The data collection methods used were observation, interview, and documentation. The validity used was triangulation of the data and method. The collected data, then, were analyzed by using interactive analysis technique consisting of three stages namely: data reduction, data display, and data verification.

\section{RESULTS AND DisCUSSION}

\section{A. Research Results}

Based on the results of the field observations conducted from August to September 2017 using observation guidelines, the following results are found: (1) students formed their groups according to religion, tribe, and social status, (2) each team clearly disrespected their friends' opinion from different religion and tribe, (3) students only visited their friends who were from the same religion and tribe, (4) they were less concern to the friends or family members who are sick, and (5) students tended to care to local and national natural disaster victims who are from the same religious and tribe only.

Likewise, the observations that the researcher did on scout coaches when giving scout training results are: (1) scout coaches did not provide insight into the knowledge of the importance of multicultural values, the coach also did not give a reprimand to students who have the behavior and acts contrary to the multicultural value. Moreover, the coaches provided less education on attitudes, behaviors, and deeds that reflect the multicultural values, and the coaches provided less exemplary attitudes, behaviors, and deeds that reflect multicultural values. The results of the field observation were supported by the results of interviews conducted on scouts of the seventh grade students while attending the scouting training. The interview results obtained the following information: students have less understanding of the multicultural in general, they did not know the benefits of multicultural values, they know the forms of multicultural values and the value of tolerance, but there is none related to a sense of concern for fellow colleagues in their school. Then, the reason why they chose friends in forming team is because they care only the fellow religion and the whole tribe.

Meanwhile, the results of the interview with the scout leaders resulted the following information: the students have little understanding of multicultural substance, they do not really know about the multicultural actualization in scout 
training, they do not know the forms of activities that can be used as multicultural actualization, and they think consensus deliberation activity is the way to instill the multicultural value.

By looking at the results of the field observations and interviews with the scout leaders and students, the real condition of multicultural values is less implemented. The impact is that the atmosphere resulted a less healthy life, jealousy, prejudice negative thoughts, discomfort in the association, and less coordination in doing something. If this condition is left, it can create an increasingly unhealthy condition of the school life, as well as great potential conflict. Therefore, it is necessary to do strategic steps as an effort to solve it.

\section{DISCUSSION}

Based on the real condition of the multicultural values on the seventh grade of SMP Negeri 1 Kartasura students mentioned above, there is a necessity to reinforce the multicultural value. The provision of reinforcement and punishment is essentially a reward for students who show positive learning behaviors expected in accordance with the learning objectives. Through the appropriate, fast, and meaningful provision of reinforcing and punishment, it is expected to repeat the same behavior, even when the students will be encouraged to always learn and create better learning behavior in further learning activities. As the notion of reinforcement according to [14], "Reinforcement is a response to a behavior that can increase the possibility of recurrence of that behavior". In the learning activities, positive responses or learning behaviors that tend to survive are reinforced, while the response or behavior of students who do not tend to recur with a better response and learning behavior did not get reinforcement.

The benefits of strengthening and punishment in the learning activities are to increase the students' attention to the lessons, to improve and to maintain students learning motivation, to ease the students learning, to control and to modify the behavior of students who are less positive and encourage the emergence of positive behavior, and to create self-confidence in students and maintains a conducive learning climate. Reinforcement and punishment given precisely, quickly, and meaningfully in the learning activities, can provide a very big influence in improving students learning motivation. Nevertheless, strengthening and punishment can also serve to stop undesirable learning behavior that will disrupt the process of learning activities and achievement of students learning outcomes. The strength and punishment given by teachers depend on the learning situation. These situations and conditions will greatly influence the application of the kind of reinforcement and punishment provided by the teacher. In relation to the type of reinforcement [14], grouped in two types, namely verbal reinforcement and nonverbal reinforcement.

In general, reinforcement is useful for students because it will increase students learning motivation, and learning motivation is one of the important things in learning because it makes someone to learn. What is the mechanism of motivation due to reinforcement? [15] Once said that every human being has a hierarchical need from the beginnings of physical needs, security, respect, love, self-actualization, and need for knowledge. In fact, the reinforcement that teachers provide is one way to meet the needs of being rewarded, loved even as one form that the subject of learning has successfully proven himself (self-actualization), when the need the subject of learning is met then he will feel the satisfaction that will encourage him to return to do the same.

Some research results that support the results of this research are as follows: the research conducted by [16], affirms that one of the teacher's personality trajectories is multicultural; therefore, the teacher must adhere to the diversity of each student and provide service by not emphasizing the different religious, ethnic, racial, cultural, and linguistic differences. Also, research results conducted by [17] concluded that the multicultural value will not be useful if only known and memorized without being done and applied in all activities both curricular and extra-curricular students including scouting exercises. Then, the research results of [18] concludes that globalization has a direct effect on the diminution of multicultural values; as a result, it needs to be strengthened in all educational activities all in formal, informal, and non-formal ways including scouting activities. The research conducted by [19] concluded that multicultural educators must understand and apply the multicultural values in the implementation of education and training activities. [20], which concluded that the reinforcement of multicultural values in students is not only the responsibility of the school but the family and society. Ref [21] concludes that teachers in performing their professional duties should appreciate the diversity of each student, and they should not discriminate students in providing services during the learning process that takes place.

From some of the above research results, some explanation is given. First, the faded multicultural values must be addressed wisely. The real action through the provision of reinforcement should be done so that the value of multicultural is stronger. Second, the efforts to strengthen the value of local wisdom in students of SMP Negeri 1 kartasura become the responsibility of family, school, and community. Third, the implementation of strengthening the value of local wisdom through scouting activities in SMP Negeri 1 kartasura was done by coaching with exemplary, reward and punishment, as well as activity-oriented scouting activities, discussions, team formation, art performances, and the other activities related to the scouting.

\section{CONCLUSION}

It can be concluded that the multicultural value reinforcement for students of SMP Negeri 1 kartasura academic year 2017-2018 was conducted through scouting activities in the form of camps, discussions, team formation, art performances, and exemplars of teachers about the behavior and deeds that reflect the multicultural values 


\section{REFERENCES}

[1] A. Azra, Merawat kemajemukan, merawat Indonesia, Institute for Multiculturalism and Pluralism Studies (Impulse), 2007.

[2] C. Geertz, D. Kuntjoro-Jakti, S. Supomo, Penjaja dan raja: perubahan sosial dan modernisasi ekonomi di dua kota Indonesia, Yayasan Obor Indonesia, 1989.

[3] V. Sanjaya, Learning Strategy, Jakarta: Kencana Prenada Media, 2011.

[4] S. Udin, Winata Putra, Strategi Belajar Mengajar, (Jakarta: Universitas Terbuka, 2005, pp 18.

[5] Nurhasnawati, Strategi Pembelajaran Micro, (Pekanbaru: Fakultas Tabiyah dan Keguruan IAIN Sultan Syarif Kasim Riau Pekanbaru, 2005), 2003, pp. 17

[6] Z. Asril, Micro teaching, Jakarta: Raja Grafindo Persada, 2010.

[7] J. J. Hasibuan and Moedjiono, Proses belajar mengajar, Penerbit PT Remaja Rosdakarya, 1995.

[8] S S. Brehm, S. M. Kassin, Gibbons FX, Developmental social psychology: Theory and research, Oxford University Press, USA; 1981 May 21.

[9] E. F. Brigham, Financial management theory and practice, Atlantic Publishers \& Distri; 1991.

[10] D. Katz, "The functional approach to the study of attitudes," Public opinion quarterly, 24(2): 1960, pp 163-204

[11] L. Festinger, A theory of cognitive dissonance, Stanford university press; 1962.

[12] R. Bogdan, S. J. Taylor, The social construction of humanness: Relationships with severely disabled people, Interpreting disability: A qualitative reader, 1992, pp 275-94

[13] L. J. Moleong, Metodologi Pendidikan Kualitatif, Bandung: Remaja Pustaka. 2007.

[14] E. Soegito, Y. Nurani, Kemampuan Dasar Mengajar, Jakarta: Pusat Penerbitan Universitas Terbuka, 2002.

[15] A. H. Maslow, "A theory of human motivation", Psychological review, 50(4), 1943, pp 370.

[16] M. Eskici, "Prospective Teachers' Personal Characteristics to Multicultural Education", Department of Educational Science, Faculty of Science and Art, Kırklareli University, Turkey Copyright, Universal Journal of Educational Research 4(12A), 2016, pp 102-111 http://www.hrpub.org DOI: 10.13189/ujer.2016.041313

[17] H. Aydin, B. Tonbuloğlu, "Graduate Students Perceptions' on Multicultural Education: A Qualitative Case Study”, Eurasian Journal of Educational Research, Issue 57 , 2014, pp 29-50

[18] N. Y. Sinyaginaa, and T.Y. Rayfschnaydera, "The policy of multicultural education in Russia focus on personal prioritiesa Russian Presidential Academy of National Economy and Public Administration, Russia", International Journal Of Environmental \& Science Education 2016, Vol. 11, No. 18, pp 12613-12628

[19] M. Abendroth, Growing in Multicultural Education with Alumni, Fall 2015 Multicultural Education, 2015.

[20] H. Sarraj, K. Bene, J. Li, \& H. Burley, Raising Cultural Awareness of Fifth-Grade Students through Multicultural Education An Action Research Study, Multicultural Education, 2015

[21] H. A. Alismail, "Multicultural Education: Teacher's Perceptions and Preparation Department Curriculum and Instruction, School of Education, University of Minnesota", Journal of Education and Practice www.iiste.org ISSN 2222-1735 (Paper) ISSN 2222-288X (Online) Vol.7, No.11, 2016 